\title{
correspondence
}

\section{Mincingly speaking}

Sir,-My good friend Ken Mellanby (7 September, page 8) fell into the trap of assuming that a word cannot have two meanings. Mincemeat is defined in dictionaries (including the Oxford Dictionary) as either (1) ground, chopped or minced meat, (2) the mixture of raisins, apples, spices etc. used on both sides of the Atlantic in mince pies. The term 'mincemeat' for ground meat may have been abbreviated to 'mince' in Huntingdon-I do not know. But, as a former Sussex man, I recall that Hilaire Belloc said that the Midlands were "sodden and unkind". I would not think of using such language myself, of course. Yours faithfully, Thomas H. Jukes

University of California

Berkeley, CA, USA

mincemeat $n$ [alter. of minced meat, fr. minced (past part. of ${ }^{1}$ mince) + meal 1 1: minced meat 2 : apples, meat and suet 3 : themething felt to resemble finely chopped meat; specif : a state of destruction or annihilation - used in the phrase make mincemeat of ascience of making in of the old-time religion - F. . Allen. Joseph)

\section{Geos III not enough for POLO}

SIR,-Your articles on the European Space Agency (ESA) (5 October, page $355)$ are timely as its activities and those of its predecessor (ESRO) have not been widely known to the European scientific community: the present discussions within ESA of future programmes are greatly hampered by this ignorance. However, your statements about the polar orbiting lunar observatory (POLO) need clarifying. You mention the proposal to use the fourth Ariane test flight in 1980 to launch a lunar satellite, building this quickly and cheaply from Geos III hardware. However this is not the POLO concept as only a small part of the necessary complement of experiments to survey the whole surface of the Moon by chemical and physical sensors could be flown on this test flight.

Your report does not make clear that a mission definition study is now being undertaken so that the POLO can be a competitor in the decision as to which mission ESA will launch in 1985. In their recent report ('An approach to long range planning 1980-1990') the ESA Solar System Working Group laid great emphasis on the desirability of European involvement in studies of the Moon and planets and smaller bodies of the solar system, and it is as a result of the interest stimulated by this report that the mission definition study of POLO has been launched. This new development in ESA's thinking recognises that many European laboratories in the last decade have done fundamental work on Apollo and USSR lunar samples, and have participated in planetary missions (see 'The Moon: a new appraisal from laboratory studies and space missions'. The Royal Society. 1977. Ed. by G. Brown, G. Eglinton, S. K. Runcorn and H. C. Urey). The Ariane rocket has progressed so successfully that Europe will have in the 1980s the technology capable of launching orbiters for scientific study around Mars, the Moon and Venus.

During the preparatory study of POLO, it has been established that there are European laboratories capable of making the experimental hardware for all the various experiments which need to be done (see experiments listed in Nature, 265, 197-199 (1977) Runcorn S. K. and Coleman P. J.) but there is now a great need for the European scientific community, particularly young physicists, chemists and geologists, to take these opportunities now unfolding in ESA seriously. Potential interest from European scientists in building experiments or making use of the data to be obtained or perhaps suggesting entirely novel experiments to be done from the orbiter, which the rather closed circle of space scientists may not have envisaged, could be very helpful in the preparatory study now proceeding. (Dr G. Haskall, European Space Agency, 8-10 rue Mario Nikis, 75738 Paris Cedex 15 will supply information.) Yours faithfully,

Department of Physics,

University of Newcastle upon Tyne, UK.

\section{Chemi-osmosis and energised protons}

SIR,-I write this letter to correct some impressions (2 November, page 8 ) left by your correspondent while describing the achievements of Dr Peter Mitchell for which the Nobel Prize was awarded. Mitchell's distinguished work in 1961 was in the development of a quantitative theory of chemi-osmosis and has been particularly used in explanation of the transduction of energy in biological systems. In this context chemi-osmosis uses a proton gradient. My contribution to this field, to which your correspondent refers most kindly, was to propose first that it was in fact energised protons which were the intermediates in energy transduction. The reference is The Enzymes, eds. P. D. Boyer, H. Lardy and K. Myrback, 1, 391; Acadamic Press 1959.

In 1961 I developed the idea of how energised protons might be used in systems which have diffusion control (J. Theoret. Biol. 1, 1; 1961) and one form of this control was independently visualised by Peter Mitchell and myself at that time. This is chemi-osmosis. Where Mitchell and I differed is that he considered this to be the actual mechanism in biological systems. Moreover he developed quantitative tests and did experiments to check his ideas. (It is also fair to add that chemi-osmosis unconnected with energy transduction and unknown to me was developed more qualitatively by Mitchell during the preceding five years. To be fair to myself, in 1961 before Mitchell's article in Nature 191, 141; 1961 was written, he had read both of my papers above).

While Mitchell developed chemi-osmosis I developed an alternative more general approach to diffusion control based on my original concept of energised protons. I think you will understand that in this context I do not accept the concluding remarks by your correspondent about Popper's use of working words. It would be easy to show that Mitchell's ideas and mine could then become lost in the word "chemi-osmosis". Mitchell's theory must be examined in terms of the equations which were derived from it. As I do not accept that chemi-osmosis is a correct description of energy transduction in biology it is very important to keep names tightly associated with ideas. Clearly if in the long term my views are to predominate it is my job to show where chemi-osmosis is incorrect and where my own ideas of localised energised protons are correct. Some papers along these lines have been published and I am about to submit a detailed proposal.

The Nobel Prize has been awarded for chemi-osmosis. In that context it has been very properly awarded to Dr Peter Mitchell and I will be the last to contest this. It so happens that I do not think that it is the correct theory of the way in which energised protons (not originally asociated with chemi-osmosis, see above) are usedn in biological systems. We shall see.

$$
\text { Yours faithfully, }
$$$$
\text { R. J. P. Williams }
$$

Inorganic Chemistry Laboratory, University of Oxord, UK

\section{US geneticists}

Sir,-I wish to make two comments in connection with the article by John Douglas, 'US geneticists look to Europe for research facilities' (21 September, page 170):

The list of sources of support of the original research leading to the procedure used in synthesising artificial genes should have included the American Cancer Society, not the National Cancer Institute.

The penultimate paragraph cites the prospective United States patent as at least a partial reason why scientists might be doing certain genetic research in Europe.

The existence of a patent per se does not inhibit research in the US or elsewhere. The only basis on which this particular patent (if granted) might become a factor in the choosing of a site of research is that, as noted earlier in the article, industrial licensees of the patent will be required to follow the NIH safety guidelines for genetic engineering. Yours faithfully,

NiELS J. ReIMERS

Office of Technology Licensing,

University of Stanford, USA 